\title{
Comparative development of sorghum, redgram and rice breeding population of Sitophilus oryzae (L.) feeding on cereals and split redgram dhal
}

\section{S. Vijay ${ }^{*}$ and K. Bhuvaneswari}

Department of Agricultural Entomology, Tamil Nadu Agricultural University, Coimbatore-641003 (Tamil Nadu), INDIA

*Corresponding author. E-mail: entovijay@gmail.com

Received: June 29, 2016; Revised received: May 18, 2017; Accepted: November 10, 2017

Abstract: Rice weevil Sitophilus oryzae (L.) mainly attacks whole grains such as wheat, corn, barley and rice and have been found actively breeding in such foods. The host range of $S$. oryzae now extended to split pulses. An experiment was carried out at the Entomology Laboratory, TNAU, Coimbatore during 2014-2015 to study the comparative development of sorghum, redgram and rice breeding population of $S$. oryzae feeding on cereals and split redgram dhal. The assessed parameters were survival percentage, per cent mortality and F1 progeny. The per cent mortality was higher in sorghum breeding population while feeding on redgram (98.33\%) and rice $(44.67 \%)$. In case of redgram breeding population per cent mortality was maximum in rice $(21.67 \%)$ and sorghum (19.67\%). The survival percentage was maximum in sorghum population while feeding on sorghum $(95 \%)$. $F_{1}$ progeny emergence of sorghum breeding population was higher while feeding on sorghum (75.67\%) and rice (36.67\%). In case redgram breeding population F1 progeny emergence was maximum in redgram (62.33\%) and sorghum (15.33\%), whereas in rice breeding population maximum progeny emergence was observed in rice $(72.33 \%)$ and sorghum $(65.67 \%)$. The cereal bred population did not survive on redgram, whereas redgram bred population able to survive on cereals, but the progeny emergence and their development was affected.

Keywords: Cereals and redgram breeding population, $F_{1}$ progeny, Per cent mortality, Survival percentage

\section{INTRODUCTION}

The rice weevil, Sitophilus oryzae (L.) (Coleoptera: Curculionidae), is one of the most destructive pest of stored cereals worldwide. It is classed as a primary pest, cosmopolitan in nature and is known to infest sound cereal seeds (Hill, 1990) and causes severe loss in rice, maize, barley and wheat (Bhatia et al., 1975; Singh et al, 1980; Neupane, 1995). Though the storage grain loss is caused by insect pests, pathogens and rodents it is generally believed that half of the storage loss is usually caused by insects (FAO, 1968). It is one such major pest, causing about 10.0 to 65.0 per cent damage in stored seed. Under prolonged storage the damage peaks has been reported up to 80.0 per cent (Park et al. 2004). Considering the loss caused by storage insect pests, effective methods of control are of paramount importance. Control often depends on a sound knowledge of the ecology and on the effects of a multitude of environmental factors on the life history of a pest.

Reports about its occurrence on legumes are scanty. Pemberton et al (1981) studied its breeding behaviour on carob, Ceratonia siliqua (L.), a tree legume native to the Mediterranean region. Coombs et al. (1977) reported the successful development by Trinidad strain of S.oryzae on yellow split pea. In India, the pest was recorded for the first time to feed on red gram at Coimbatore. Population of rice weevil feeding on split red gram dhal was collected and sent to IARI, and it was identified as Sitophilus oryzae by Dr. V.V. Ramamoorthy, Principal Scientist, Entomology Division (Personal communication, 2011). In the present investigation, comparison between the populations of $S$. oryzae feeding on sorghum, rice and split redgram was assessed in terms of survival per centage, per cent mortality and $\mathrm{F}_{1}$ progeny

\section{MATERIALS AND METHODS}

The three populations of rice weevil, $S$. oryzae, was mass cultured on their respective hosts namely sorghum, red gram and rice under laboratory. The development of population reared on redgram was studied in comparison to that of sorghum and rice. The experiment was laid out in a Completely Randomized Design (CRD) with nine treatments under room temperature condition. In a small plastic container with punctured lid, 100 grains from each material sample were placed. Each container was infested with 10 pairs of one week old adult rice weevils. Weevil sex was determined by rostra length and rostra pit discrimination (Reddy, 1951) and by abdominal tip shape (Qureshi, 1963).

An experiment was laid out to study the host feeding variation of cereals and redgram breeding population. 
For each population suitability of the food materials viz., rice, sorghum and redgram was assessed through feeding experiments, in terms of per cent mortality, survival percentage and progeny emergence. In a small plastic container with punctured lid, 100 grains from each food material sample were placed and infested with 10 pairs of one week old adult rice weevils. Observation was made on per cent mortality, survival percentage from 7 days after release of the adults. For $\mathrm{F}_{1}$ progeny study, released adults were separated from test materials via a \#10 sieve and discarded after a week period and then the samples were replaced in their respective containers. Each container was carefully observed on daily basis, beginning on the $30^{\text {th }}$ day of removal. Emerging progenies in each container were separated from the sample grain daily via \#10 sieve, counted and then discarded. This process continued until there was no progeny emergence in all containers.

\section{RESULTS AND DISCUSSION}

The experiment was conducted to compare the suitability of sorghum, redgram and rice breeding population of $S$. oryzae maintained in the laboratory condition. The original hosts were inter changed to assess their suitability in terms of per cent mortality, survival percentage and progeny emergence. The per cent mortality of sorghum breeding population was significantly higher in redgram $(98.33 \%)$ followed by rice $(44.67 \%)$ and sorghum $(5.00 \%)$. In case of redgram

Table 1. Treatment details.

\begin{tabular}{ll}
\hline Treatment & Particulars \\
\hline 1 & Sorghum population fed on rice \\
2 & Sorghum population fed on redgram \\
3 & Sorghum population fed on sorghum \\
4 & Redgram population fed on rice \\
5 & Redgram population fed on redgram \\
6 & Redgram population fed on sorghum \\
7 & Rice population fed on rice \\
8 & Rice population fed on redgram \\
9 & Rice population fed on sorghum \\
\hline
\end{tabular}

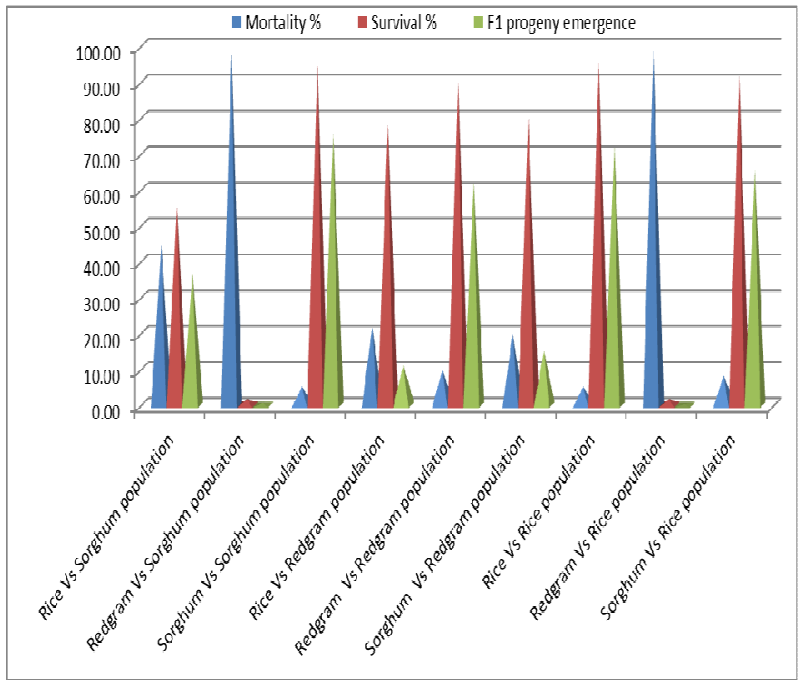

Fig. 1. Graphical representation of sorghum, redgram and rice population of S.oryzae feeding on cereals and split red gram dhal.

breeding population the per cent mortality was significantly maximum in rice $(21.67 \%)$ followed by sorghum $(19.67 \%)$ and redgram $(10.00 \%)$, whereas in rice breeding population it was maximum in redgram $(98.33 \%)$ followed by sorghum $(8.33 \%)$ and rice $(5.00 \%)$ respectively (Table 2 ).

The survival percentage of sorghum breeding population was significantly higher in sorghum $(95.33 \%)$ followed by rice $(55.33 \%)$ and redgram $(1.67 \%)$. In case of redgram breeding population the survival percentage was maximum in redgram $(90.00 \%)$ followed by sorghum $(80.34 \%)$ and rice $(78.33 \%)$, whereas in rice breeding population the maximum per centage of survival was observed in rice $(95.00 \%)$ followed by sorghum $(91.67 \%)$ and redgram $(1.67 \%)$ respectively (Table 1). $F_{1}$ progeny emergence of sorghum breeding population was significantly higher in sorghum $(75.67 \%)$ followed by rice $(36.67 \%)$ and redgram $(0.67$ $\%)$. In case of redgram breeding population, the $\mathrm{F}_{1}$ progeny emergence was significantly maximum in

Table 2. Comparative study of sorghum, redgram and rice population of S. oryzae feeding on sorghum, red gram and rice.

\begin{tabular}{lllll}
\hline S.N. & Treatments & Mortality \%(7 DAR) $^{*}$ & Survival \% (7 DAR)* $^{*}$ & F1 progeny emergence $^{\#}$ \\
\hline 1 & Sorghum population fed on rice & $44.67(41.94)^{\mathrm{b}}$ & $55.33(48.06)^{\mathrm{d}}$ & $36.67 \pm 0.58(4.12)^{\mathrm{b}}$ \\
2 & Sorghum population fed on redgram & $98.33(82.58)^{\mathrm{a}}$ & $1.67(7.42)^{\mathrm{e}}$ & $0.67 \pm 1.15(0.82)^{\mathrm{c}}$ \\
3 & Sorghum population fed on sorghum & $5.00(12.92)^{\mathrm{de}}$ & $95.00(77.08)^{\mathrm{ab}}$ & $75.67 \pm 0.58(8.70)^{\mathrm{a}}$ \\
4 & Redgram population fed on rice & $21.67(27.74)^{\mathrm{c}}$ & $78.33(62.26)^{\mathrm{c}}$ & $11.33 \pm 1.08(3.37)^{\mathrm{b}}$ \\
5 & Redgram population fed on redgram & $10.00(18.43)^{\mathrm{d}}$ & $90.00(71.57)^{\mathrm{b}}$ & $62.33 \pm 2.51(7.90)^{\mathrm{a}}$ \\
6 & Redgram population fed on sorghum & $19.67(26.33)^{\mathrm{e}}$ & $80.34(63.67)^{\mathrm{a}}$ & $15.33 \pm 0.58(3.90)^{\mathrm{b}}$ \\
7 & Rice population fed on rice & $5.00(12.92)^{\mathrm{ce}}$ & $95.00(77.08)^{\mathrm{ab}}$ & $72.33 \pm 2.52(8.50)^{\mathrm{a}}$ \\
8 & Rice population fed on redgram & $98.33(82.58)^{\mathrm{a}}$ & $1.67(7.42)^{\mathrm{e}}$ & $0.33 \pm 0.58(0.58)^{\mathrm{c}}$ \\
9 & Rice population fed on sorghum & $8.33(16.78)^{\mathrm{d}}$ & $91.67(73.22)^{\mathrm{b}}$ & $65.67 \pm 1.44(8.10)^{\mathrm{a}}$ \\
& SEd & 4.2388 & 4.2388 & 0.3341 \\
& CD $(0.05)$ & 8.9054 & 8.9054 & 0.7020 \\
\hline
\end{tabular}

* Mean of three replications. Figures in parentheses are square root transformed values. Mean followed by same letter (s) in a column are not significantly different by DMRT $(\mathrm{P}=0.05)$, ${ }^{\#}$ Figures in parentheses are arc sin transformed values. Mean followed by same letter (s) in a column are not significantly different by DMRT $(\mathrm{P}=0.05)$ 
redgram $(62.33 \%)$ followed by sorghum $(15.33 \%)$ and rice $(11.33 \%)$, whereas in rice breeding population maximum progeny emergence was observed in rice $(72.33 \%)$ followed by sorghum $(65.67 \%)$ and redgram $(0.33 \%)$ respectively (Fig .1). In case of split red gram seed size influenced the progeny production of $S$. oryzae. However, the size of legumes can not be compared with sorghum, with respect to progeny production. This is because sorghum being the traditional host of $S$. oryzae, hence higher reproduction is expected.

The observations revealed that sorghum and rice breeding populations were not able to survive on redgram, whereas red gram breeding population was able to survive on cereals but their development and progeny emergence were affected.

The present findings are in accordance with Coombs et al. (1977), Pemberton and De - Rodriguez (1981) who reported that the evolution of the ability to feed and breed on peas seems to have occurred recently in cereal weevils. The great barriers to feeding on legumes which $S$. oryzae needs to overcome are the toxicants present in most leguminosae which contains a wide range of phytotoxins with an insecticidal functions (Harbone, 1982). Adaptation processes of herbivorous insects to deleterious plant allelochemicals include various strategies such as sequestration, target site insensitivity, occurrence of surfactants and/or an alkaline $\mathrm{pH}$ in the gut, differential absorption by the peritrophic membrane, induction of detoxifying enzymes, and excretion (Slansky, 1992). Non legume feeding adult S. oryzae die on yellow split peas because of intake of toxins, rather than through the effects of antifeedants (Holloway, 1986).

The present findings are in conformity with study of Grenier et al., (1997) who found that rice weevils fed on peas, had enhanced adult survival and reproduction after removal from the legume. This may be indirect evidence for an allelochemical-induced beneficial enzyme systems in this species. By studying enzyme activities, Baker and Woo (1992) showed that despite a small decrease in beta-glucosidase activity in the gut of pea-breeding weevils when transferred to wheat, there was no obvious relationship between beta-glucosidase activity in adults and their adaptation to feeding and breeding on legumes.

The present findings are in agreement with Holloway and Mackness (1988) who described mechanisms of detoxification of legume secondary compounds in legume feeding $S$. oryzae. They studied pea resistant and susceptible weevil strains (only breeding on wheat) on six legume seeds: adzuki bean (Vigna angularis), split pea (Pisum sativum), brown lentil (Lens esculenta), cowpea (Phaseolus vulgaris), green gram (Vigna radiata) and soybean (Glycine max). Wheat breeding populations survived very poorly on legumes, whereas the legume-breeding populations survived better. Soy- bean was clearly more toxic than the five other legumes.

\section{Conclusion}

It was concluded that the cereal bred population did not survive on redgram. While redgram bred population able to survive on cereals, but the progeny emergence and their development was affected. This may be due to some evolutionary changes of the S.oryzae population. It may attribute to the nutritional characteristics and few nucleotides variation between the sorghum and redgram bred population.

\section{ACKNOWLEDGEMENTS}

Authors would like to acknowledge University Grant Commission, New Delhi for the financial support for this study.

\section{REFERENCES}

Baker, J. E. and Woo, S. M. (1992). Beta-glucosidases in the rice weevil, Sitophilus oyzae: Purification, properties, and activity levels in wheat and legume feeding strains. Insect Biochem. Mol. Biol., 22: 495- 504.

Bhatia, S. K., Singh, V. S. and Bansal, M. G. (1975). Varietal resistance in barley grain to laboratory infestation of rice weevil and lesser grain borer. Bulletin of Grain Technology 13 (2): 69-72.

Coombs, C. W., Billings, C. J. and Porter, J. E. (1977). The effect of yellow split-peas (Pisum sativum L.) and other pulses on the productivity of certain strains of Sitophilus oryzae (L.) (Coleoptera: Curculionidae) and the ability of other strains to breed thereon. J. Stored Prod. Res., 13: 53-58.

FAO, (1968). Rice grain of life. International Rice Year 1966: Freedom from hunger. World Food Problems No. 6. Food and Agriculture Organization of the United Nations, Rome, Italy $65 \mathrm{p}$.

Grenier, A. M., Mbaiguin, M. and Delobel, B. (1997). Genetical analysis of the ability of the rice weevil Sitophilus oryzae (Coleoptera: Curculionidae) to breed on split peas. Heredity, 79: 15-23.

Harbone, J. B. (1982). Introduction to Ecological Biochemistry, $2^{\text {nd }}$ edn. Academic Press, London.

Hill, D. S. (1990). Pests of stored products and their control, Belhaven press, London

Holloway, G. J. (1986) . A theoretical examination of the classical theory of inheritance of insecticide resistance and the genetics of time to knockdown and dry body weight in Sitophilus oryzae (L.) (Coleoptera: Curculionidae). Bull. ent. Res., 76: 661- 670.

Holloway, G. J. and Mackness, M. 1. (1988). The evolutionary adaptation of enzyme systems in Sitophilus oryzae fed on toxic legumes. Entomol. Exp. Appl., 48:165 - 172.

Neupane, F. P. (1995). Agricultural Entomology in Nepal. Review of Agricultural Entomology 83 (12): 1291-1304.

Park, C., Peterson, S., Zhao, J. R. and Coats. (2004). Fumigation toxicity of volatile natural and synthetic cyanohydrins to stored-product pests and activity as soil fumigants. Pest Management Science, 60: 833-838.

Pemberton, G. W. and De-Rodriguez, A. D. 1981. The oc- 
currence of a rice strain of S.oryzae (L.) (Col. Curculionidae) breeding in Portugese kibbled carobs. J. Stored Prod. Res., 17:37-38.

Qureshi, A. H. (1963). Some sex differences in the granary weevil, Sitophilus granarius (L.). The Can. Entomol., 27: 13-16.

Reddy, D. P. (1951). Ecological studies of the rice weevil. $J$. Econ. Entomol., 43: 203-206.
Singh, V. S., Bhatia, S. K. and Murthy, B. N. (1980). Effect of hull on the resistance of barley varieties to the rice weevil Sitophilus oryzae L. infestation. Indian Journal of Entomology 42 (4): 576-581.

Slansky, F. J. (1992). Allelochemical-nutrient interaction in herbivore nutritional ecology. In: Rosenthal, G. A. and Berenhaum, M. R. (Eds.) Herbivores: Their interactions with secondary plant metabolites, Vol. II, Evolutionary and Ecological Processes, $2^{\text {nd }}$ edn, pp. 135-174. Academic Press, New York. 